
Arrangements

MARIANNE P. BITLER, JONAH B. GELBACH, HILARY W. HOYNES

WR-1 11 1-NICHD/NIA

October 2003

LP 03-28

This product is part of the RAND Labor and Population working paper series. RAND working papers are intended to share researchers' latest findings and to solicit informal peer review. They have been approved for circulation by RAND Labor and Population but have not been formally edited or peer reviewed. Unless otherwise indicated, working papers car be quoted and cited without permission of the author, provided the source is clearly referred to as a working paper. RAND's publications do not necessarily reflect the opinions of its research clients and sponsors. 



\title{
Welfare Reform and Children's Living Arrangements *
}

\author{
Marianne P. Bitler \\ RAND Corporation and $\mathrm{IZA}^{\dagger}$
}

Jonah B. Gelbach

University of Maryland

Hilary W. Hoynes

University of California, Davis and NBER

This version: October 14, 2003

First version: September 2003

JEL classification: I3, JI

Key words: welfare reform, living arrangements

\begin{abstract}
Relatively little is known about the impact of welfare reform on children's living arrangements, which was an important focus of reformers. We use data from the March CPS to examine this question. Our findings suggest three main conclusions. First, welfare reform in some cases has had large effects on parental co-residence among children. Second, those effects are neither entirely aligned with the stated goals of reform nor entirely in spite of these goals. Third, there is a great deal of treatment effect heterogeneity both with respect to racial and ethnic groups and with respect to whether reforms were waivers, TANF in states that had waivers, or TANF in states that did not.
\end{abstract}

${ }^{*}$ Results discussed in this paper previously circulated under the title "The Impact of Welfare Reform on Living Arrangements" and supercede the results in that paper. The views and conclusions are those of the authors and do not necessarily represent those of NICHD, NIA, or the RAND Corporation. We thank Ken Chay, Mary Daly, Keenan Dworak-Fisher, Bill Evans, Steven Haider, Judy Hellerstein, Jacob Klerman, Charles Michalopoulos, Ed Montgomery, Anne Polivka, Dan Rosenbaum, Seth Sanders, Bob Schoeni, Jay Stewart, Steve Stillman, Madeline Zavodny, and participants of the UC Davis Brown Bag, RAND Brown Bag, Bay Area Labor Economists Meeting, Southern Economics Association Meeting, and UC Santa Cruz, Cornell, Kentucky, Northwestern, University of Chicago, University of Maryland Labor/Public, and Bureau of Labor Statistics seminars for their valuable comments. We also thank Aaron Yelowitz for providing data on Medicaid expansions. Excellent research assistance was provided by Alana Harris, Gillian van Oosten, and Jared Rodecker. Bitler gratefully acknowledges the financial support of the National Institute of Child Health and Human Development and the National Institute on Aging. Correspondence to Hoynes at UC Davis, Department of Economics, 1152 Social Sciences and Humanities Building, One Shields Avenue, Davis, CA 95616-8578, phone (530) 752-3226, fax (530) 752-9382, or hwhoynes@ucdavis.edu; Gelbach at gelbach@glue.umd.edu; or Bitler at bitler@rand.org.

${ }^{\dagger}$ Institute for the Study of Labor, Bonn, Germany 



\section{Introduction}

Effects of government poverty alleviation programs on labor supply, fertility, marriage, and living arrangements have been the subject of a large and varied literature among economists, demographers, sociologists, and others. Over the last few decades, increasing numbers of children have spent time in single parent households, either because of divorce or because their mothers were never married. Few question that changes in family structure could have wide-ranging impacts on children's outcomes.

Concerns that welfare programs provide adverse incentives to work and form intact families have generated major state and federal reforms to welfare programs over the past 10 years. The widespread use in the United States of state waivers from the former Aid to Families with Dependent Children (AFDC) program in the early 1990s, followed by the passage of the 1996 Personal Responsibility and Work Opportunity Act (PRWORA), substantially changed the economic incentives facing low income individuals with children or considering having children. In particular, these reforms dramatically reduced the lifetime generosity of state welfare programs by imposing time limits, strengthening work requirements, and limiting the population eligible for assistance.

Existing literature on the effects of these reforms, which we discuss in more detail in section 2 below, focuses mainly on state welfare caseloads and labor market outcomes. While a few recent papers have considered marriage, headship, and fertility, relatively little attention has been paid to living arrangements defined more broadly. This relative dearth of research on living arrangements is somewhat surprising, given that changes in living arrangements were a key objective of the reforms of the 1990s. As stated in the text of PRWORA, the purpose of Temporary Assistance to Needy Families (TANF), which replaced AFDC, is to ${ }^{1}$

increase State flexibility in operating programs designed to: (1) provide assistance to needy families so that children may be cared for in their own homes or in the homes of relatives; (2) end the dependence of needy parents on government benefits by promoting job preparation, work, and marriage; (3) prevent and reduce the incidence of out-of-

\footnotetext{
${ }^{1}$ The full text of PRWORA can be found by searching on "H.R. 3734" at http://thomas.loc.gov/home/c104query.html.
} 
wedlock pregnancies and establish annual numerical goals for preventing and reducing the incidence of these pregnancies; and (4) encourage the formation and maintenance of two-parent families.

Each of these four goals explicitly involves issues related to living arrangements. In this paper we address these issues by examining comprehensively the impact of waivers and the 1996 Federal reform on children's living arrangements using the March Current Population Survey (CPS) for survey years 1989-2000.

Examining both state waivers and Federal welfare reform requires a "dual treatment" specification that is complicated by the fact that not all states had waivers prior to the federal reform. We find that in some cases, the results depend on how one specifies the treatment variables. In particular, there seems to be important heterogeneity in the PRWORA treatment effect across states depending on whether they had a waiver in place prior to the Federal reform. A second set of methodological issues involves CPS coding of family relationships. CPS rules cause major difficulties in interpreting the estimated impact of welfare reform on common measures of "family status" (e.g., presence of subfamilies in the household and female headship status) that would seem natural candidates for study. We construct a set of measures of living arrangements that are less subject to these interpretation problems.

We analyze the impact of reform on parental co-residence (e.g., whether the child lives with any parent, and if so whether the parent is married) and the propensity to be in a three-generation household. ${ }^{2}$ We augment the core CPS data with welfare reform variables including the presence and timing of state waivers and the timing of state implementation of the PRWORA legislation. We also include state-level controls for Medicaid generosity, labor market conditions, and other measures of welfare program parameters. We estimate pooled cross-sectional models relating outcomes to these state-level variables, a small number of demographic controls, and state and year fixed effects. Hence, the effects of welfare reform are identified through variation in the timing and incidence of reforms across states. We also examine extensions of the basic model by including state linear time trends, leads of policy variables, and alternative coding of reform variables. Because of differences in the likelihood of being affected by welfare, our work allows for separate estimates for

\footnotetext{
${ }^{2}$ For space reasons, we do not consider women's living arrangements in this paper. Our earlier paper, Bitler, Gelbach \& Hoynes (2002), examined both children's and women's living arrangements.
} 
blacks, Hispanics, and whites. ${ }^{3}$

Our results show that among black children, TANF implementation is associated with a large -2 to 4 percentage points - reduction in the fraction living with an unmarried parent and an increase in the fraction living with a married parent. However, we also find a large increase -3 to 7 percentage points - in the fraction of these children living with neither parent. Effects of welfare waivers show the same patterns, but with somewhat smaller effects.

We find somewhat different effects for Hispanics. Among Hispanic children, the effect of reform is more mixed and is less likely to be statistically significant. We find that reform is associated with reductions in the fraction of Hispanic children living with an unmarried parent but find no evidence that reform is associated with an increase in the fraction of children living with neither parent.

While these differences across groups may seem surprising, as we discuss below, the impacts of these welfare reforms on marital status and living arrangements is theoretically ambiguous in many cases. Moreover, baseline, pre-reform living arrangements are radically different across demographic subsamples; there is thus little reason to believe treatment effects should be similar. We find little evidence of any significant effects of reform among samples of whites. Given their low participation rate in welfare programs, this result can be thought of as a successful specification check.

The remainder of the paper proceeds as follows. Section 2 provides a selected review of the literature on welfare reform, labor market outcomes, marriage, and fertility. In section 3 we discuss the expected effects of welfare reform on living arrangements. In section 4 we describe our data, while in section 5 we discuss our empirical models. We report the main results in section 6 and extensions in section 7 , and we conclude in section 8 .

\section{Literature Review}

A large share of recent research on welfare reform has focused on reform's impact on state welfare caseloads (e.g., Blank (2001), CEA (1997), CEA (1999), Moffitt (1999), Schoeni \& Blank (2000), Wallace \& Blank (1999), Ziliak, Figlio, Davis \& Connolly (2000), and Haider \& Klerman (Forthcoming)). For the most part, these authors find that welfare reform has led to significant reductions

\footnotetext{
${ }^{3}$ Throughout the paper, we use "black" as shorthand for "non-Hispanic black" and "white" as shorthand for "non-Hispanic white".
} 
in welfare caseloads, with somewhat larger impacts of implementation of TANF compared to the state welfare waivers. ${ }^{4}$

The caseload literature is the subject of a recent comprehensive review by Bell (2001), who makes two important points that will be useful to keep in mind here. First, while researchers have made substantial efforts to attribute effects to specific characteristics of welfare reformincluding time limits, sanctions, family caps, enhanced earnings disregards, and tightened work exemptions - no clear pattern of statistically significant results has developed in the literature. This is particularly striking given that most researchers have strong priors concerning the likely effects of, say, time limits on caseloads. As we discuss below, expectations are weaker concerning the direction of effect reforms can be expected to have on living arrangements. It is not surprising, then, that we are also unable to attribute the effects of welfare reform on living arrangements to specific characteristics of reform. Second, Bell argues that there is no clear consensus regarding the importance of specifying the dynamic patterns of reform's effects on caseloads (e.g., including leads and lags of policy variables). Partly for this reason, our preferred results do not consider dynamics; nonetheless, we do consider the sensitivity of our results to inclusion of state-specific trends and leads of reform policy variables.

Another series of studies focuses on the relationship between welfare reform and employment, earnings, and income using nationally representative household survey data (e.g., Meyer \& Rosenbaum (2000), Moffitt (1999), Ribar (2002), Schoeni \& Blank (2000), Lewis (2002)). The studies consistently show that reforms led to increases in employment, while results for earnings, income, and poverty are less strong. ${ }^{5}$

State-level randomized experiments present another source for results on the effects of reform on family structure and living arrangements. For example, Hu (2001) finds that California's waiver expanding eligibility for two-parent families led to increases in the likelihood of staying married. Duncan \& Chase-Lansdale (2001) review the results of four major state experiments and again

\footnotetext{
${ }^{4}$ Grogger \& Michalopoulos (2003) make the point that some women-namely those for whom time limits could be binding - may rationally respond to time limits by forgoing current welfare participation in order to "bank" years of welfare for future use, perhaps explaining part of the caseload reductions.

${ }^{5}$ Also relevant are "leaver" studies that analyze random samples of women who leave welfare. The leaver studies find the majority of women who left welfare in the 1990s are employed (e.g., Moffitt \& Stevens (2000)). While these data are very useful in understanding the circumstances of prior welfare recipients, they are not ideal for estimating the effect of welfare reform. They typically track only women who responded to the incentives embodied in the reforms. Moreover, by definition, these studies cannot identify outcomes for women who never take up benefits.
} 
find mixed evidence about marriage. In one of the four studies (MFIP in Minnesota), marriage increased through reductions in divorce and increases in initial entry into marriage, while in the other studies there were no statistically significant changes.

A growing number of authors have considered women's living arrangements and welfare reform. ${ }^{6}$ This literature is likely to be partially informative about children's outcomes, but if one response to reform is for other older relatives to care for children, then focusing on single mothers, welfare recipients, or even all women of maternal age will not tell us about these changes. For example, Casper \& Bryson (1998) find that the share of children residing with grandparents has risen from 3.2 percent in the 1970s to 5.5 percent in the late 1990s, while Cox \& Pebley (1999) find that grandparent-led families are more likely to receive welfare benefits than other families. Moreover, while overall caseloads have fallen drastically over the past several years, the child-only caseload rose over much of the 1990s (Farrell, Fishman, Laud \& Allen (2000)). While states have great latitude to define eligibility for TANF funds, Ehrle, Geen \& Clark (2001) report that in all states but Wisconsin, children cared for by kin are eligible for child-only funds. Hence, changes in living arrangements are one way in which eligibility-restricting welfare reforms could be circumvented.

It is surprising how little econometric research focuses directly on welfare reform and children's living arrangements. One exception is Paxson \& Waldfogel (2003), who look at one dimension of children's living arrangements using state-level administrative data from child welfare agencies and find that TANF is associated with increases in numbers of children in out-of-home care (e.g., foster care, living with relatives). Additionally, some authors (e.g., Bloom, Scrivener, Michalopoulos, Morris, Hendra, Adams-Ciardullo \& Walter (2002)) using data from the randomized welfare experiments have examined children's living arrangements. ${ }^{7}$ While randomized experiments have all the usual advantages in terms of uncontroversial identification, they typically have relatively small samples - at most several hundred observations in each of the treatment and control groups. Even for measures of living arrangements that change substantially, significant effects may be difficult to

\footnotetext{
${ }^{6}$ Examples include Casper \& Bryson (1998), Cox \& Pebley (1999), Grogger (2003), Fitzgerald \& Ribar (2003), Susin \& Adler (2002), Horvath-Rose \& Peters (2001), Kearney (Forthcoming), Kaestner \& Kaushal (Forthcoming), Moffitt (1999), Lewis (2002), Dyer \& Fairlie (2001), and Schoeni \& Blank (2000)).

${ }^{7}$ One problem with using the recent evaluation data to examine children's living arrangements is that the only information about children is collected as part of surveys of the former recipients (treatment and controls) several years after random assignment. Thus, the data only contain detailed information for children who are co-resident. Bloom et al. (2002) find that AFDC (control group) recipients were more likely to not live with their children than were Job's First (treatment group) recipients.
} 
discern in these sample sizes.

Other studies that consider children's living arrangements and welfare reform rely only on timeseries data. For example, in a report covered on the front page of the New York Times, Dupree \& Primus (2001) use CPS data to examine national trends in children's living arrangements by race, ethnicity, and income. They find that between 1995 and 2000, there was a 1.5 percentage point decline in the number of children living with single mothers, virtually all of which can be accounted for by increases in cohabitation of single mothers with adult males to whom they are not married. Most of this change occurred between 1999 and 2000, and much of it was concentrated among black children. London (1998) also considers cohabitation and living arrangements, though her study focuses more on women than on children and includes data only through 1995. Additional recent research specifically concerning nationwide trends in children's living arrangements is reported by Ehrle et al. (2001) and Acs \& Nelson (2001). While such research is informative, it does not make use of the substantial variation in the timing and incidence of state-level welfare reforms. As such, it is difficult to know how much of the trends in living arrangements can be attributed to sources other than welfare policy, and how much is explained by measures of welfare reform after partialing out these other influences. By controlling for state labor market conditions as well as state and year fixed effects, we try to address this concern.

\section{Expected Impact of Welfare Reform on Living Arrangements}

We begin this section by describing the nature of recent reforms. Beginning in the early 1990s, many states were granted waivers to make changes to their AFDC programs. As shown in the top panel of Table 1, about half of the states implemented some sort of welfare waiver between 1993 and 1995. On the heels of this state experimentation, PRWORA was enacted in 1996, replacing AFDC with TANF. The main reform elements of PRWORA include work requirements and both continuous-use and lifetime time limits, as well as the potential for restricting eligibility for certain groups such as teen parents. However, the law leaves substantial scope for states to design and

implement their TANF programs. While the nature of PRWORA and waivers varied considerably across states, in general the changes led to a reduction in the generosity of welfare, except in some cases when combined with work or marriage. 
It is useful to classify the specific elements of welfare reform according to two dimensions: (1) whether the specific policy is "tightening" (making less generous) or "loosening" (making more generous), and (2) whether the policy affects the financial incentives associated with living arrangements directly or indirectly via effects on behavioral incentives more generally. Table 2 presents the major elements of welfare reform along these two dimensions. This range of reforms were present (to varying degrees) in both state waivers as well as the subsequent state TANF programs. Policies that are general and tightening include work requirements, financial sanctions, and time limits. General loosening provisions include liberalizing earnings disregards (lowering the tax rate on earned income while on welfare), and increasing asset limits. Tightening provisions that directly affect financial incentives associated with living arrangements include "family caps" (whereby welfare benefits do not increase with additional children born on aid), and residency requirements (whereby unmarried teen parents must live in the household of a parent or other guardian). Loosening provisions directly associated with family structure include expanding eligibility for two-parent families.

We summarize expected effects of various reforms in Table 2. It is helpful to consider separately those reforms that directly change incentives for particular living situations ("specific reforms") and more general reforms that have indirect effects. Specific reforms lead to clear and simple ceteris paribus predictions concerning living arrangements. Family caps should reduce welfare fertility (specifically non-first births). Teen residency requirements should lead to increases in household size, and in particular should lead to more three-generation households. Finally, liberalizing the eligibility requirements for two-parent families (e.g., eliminating the AFDC-UP 100-hour rule) should reduce the incentive for (nonmarital) female headship and increase marriage.

As for general reforms, tightening reforms reduce access to welfare, so they should also reduce the relative desirability of remaining unmarried. Thus, we expect tightening general reforms to increase the probability that children live in married-couple households, while reducing the probability of living in female-headed households. Tightening aspects of reform may have additional effects, because they can be expected to cause fiscal stress in heavily welfare-dependent families. This expectation has been borne out empirically in the literature discussed above, as reforms appear to have caused reductions in welfare participation without substantial increases in income. Fiscal stress might cause a wide variety of changes in living arrangements, e.g., tightening could cause families to double up in the same household (e.g., a mother and child might move in with grandparents or some 
other relative). This outcome might be especially common for young parents facing termination due to teen residency requirements. ${ }^{8}$

Another possible effect of fiscal stress is for children to leave their parent's household and move in with relatives. Conversely, parents might leave three-generation households, perhaps because of pressure from their own parents. These changes might also occur when parents face time limits or work sanctions, since children generally are eligible for child-only benefits if they live with neither parent, regardless of the income of the new household. The general welfare loosening reforms would, of course, lead to the opposite predictions: decreases in marriage, increases in nonmarital births, and decreases in fiscal stress.

A further reason to expect treatment-effect heterogeneity concerns immigration status. Illegal immigrants are not eligible for cash assistance under PRWORA, just as they were ineligible for AFDC (U.S. House of Representatives Committee on Ways and Means (2000)). However, AFDC was available to many legal immigrants until 1996. PRWORA and subsequent legislation have greatly restricted use of federal funds for legal immigrants in the first five years after entry. ${ }^{9}$ After that period, states have the option to provide TANF funds to legal immigrants. Subgroups with a large share of recent immigrants might face quite different incentives to marry, divorce, or alter living arrangements than do subgroups primarily composed of the naturalized or native-born.

In sum, there is no single, clean prediction of the impact of welfare reform on children's living arrangements. In addition, different aspects of reform lead to opposite predictions about these outcomes. The net impact of reform is thus an empirical question.

\footnotetext{
${ }^{8}$ The welfare implications of changed living arrangements are often ambiguous. For example, in the case of teen parents moving in with their own parents, one might argue that one or both of the two younger-generation children is better off living in a household with older adults. On the other hand, the household is likely to be more crowded, and there may have been good reasons for the middle generation to move out (e.g., physical abuse). That said, DeLeire \& Kalil (2002) find that adolescent children of single parents living in three-generation households have outcomes at least as good as do children living in two-parent families, while replicating the findings of many researchers that teens living with only one parent and no grandparents suffer worse outcomes than teens living with two parents.

${ }^{9}$ States are allowed to provide "state-only" funds to these immigrants, and some (e.g., California) do so.
} 


\section{CPS Data, Coding Issues, and Outcomes}

\subsection{CPS data}

We use data from the March Current Population Surveys (CPS) for survey years 1989-2000. The March CPS is an annual demographic file of between 50,000 and 62,000 households and includes detailed information about the persons and families living in each household. ${ }^{10}$ The CPS provides information on demographics and family structure at the time of the survey as well as household income information covering the preceding calendar year. We choose to begin the sample in 1989 for three reasons. First, there was essentially no activity in welfare waivers until the early 1990s, so adding earlier years would do little to identify effects of reform. Second, by starting in 1989, we are able to use data during a complete business cycle, from the peak in the late 1980s, through the early 1990s recession, and then through the long expansion of the 1990s. Third, beginning with the 1989 survey allows more continuity in our construction of key outcome variables. ${ }^{11}$

We stop with the 2000 March survey because all state TANF programs were implemented by the end of January 1998. This means that there is no variation in our TANF reform dummy variable (see below) after the March 1998 survey. As a consequence, data from surveys after March 1998 add no identifying variation. We offer a detailed econometric discussion of this fact in Bitler, Gelbach \& Hoynes (2003, (Papers and Proceedings)). We choose to include the March 1999 and March 2000 data to facilitate estimation of economic trends throughout the business cycle; dropping these years makes no substantive difference in our results for welfare reform's effects. We do not add data after the March 2000 survey because the long economic expansion waned thereafter.

\footnotetext{
${ }^{10}$ We use the CPS for several important reasons. First, the March CPS provides very large samples. A recent National Research Council report argues that the CPS is the only nationally representative survey data with large enough sample sizes to identify the effects of welfare reform on subpopulations of interest (Moffitt \& Ploeg (2001)). The CPS is also available through the year 2000, allowing us to include several years of data post-TANF implementation. Other data sets are available only with a long lag, making analysis of the post-1996 TANF reforms impossible. For example, the Survey of Income and Program Participation (SIPP) data are available only through the 1996 panel, and SIPP sample sizes are considerably smaller than those in the CPS. Moreover, the SIPP's primary advantage for our purposes would be its "relationship" roster or matrix, which provides detailed pairwise relationship information for every person pair in a household. Unfortunately, the relationship module is available only in the second wave of SIPP panels. As a result, there would be no extended relationship data available for later years. Some other data sets do not cover the period of TANF implementation at all; for example, the most recent available wave of the National Survey of Family Growth is the 1995 wave. Others, like the National Survey of American Families, have no pre-reform data at all. Longer panels such as the Panel Survey of Income Dynamics or the National Longitudinal Surveys of Youth offer small samples.

${ }^{11}$ CPS coding changed in 1989. In some cases, within-household relationships were treated differently before then, so that earlier data would not necessarily be comparable to data for 1989-2000.
} 
Our sample consists of March CPS children, whom we define as those aged younger than 16. We use this restrictive definition of children in order to avoid including a large number of potential teen parents as children, since teen parenthood is potentially endogenous to welfare reform. By design, a given household is surveyed in two consecutive CPS March samples, but because the CPS is a household rather than population survey, people who move between Marches are replaced by whoever moves into the household. To minimize any biases arising from the possibility of nonrandom movers, for each sample we select only those respondents whose households are in the first four months-in-sample. This approach also allows us to avoid covariance estimation problems arising from dependent unobservables for repeatedly-observed households, an issue often left unaddressed in studies using the March CPS. Combining all the years 1989-2000, our sample contain 209,385 children.

\subsection{CPS coding issues and living arrangements}

CPS households consist of a group of people - related or not — who together occupy a housing unit. If two or more persons living together are related by birth, marriage, or adoption, they constitute a CPS family. If the householder is part of a family, then that family is called the primary family. Interestingly, CPS household headship is determined by the name on the mortgage or lease for the housing unit. A subfamily is a family that does not include this person, and subfamilies, are called related or unrelated depending on whether subfamilies' members are related to the primary family. The key fact about these coding rules is that headship and subfamily status depend on who pays the rent. To see how this can matter, suppose that a woman and her child live with the woman's male partner, who is neither the child's father nor married to the woman. If the male partner pays the rent (he is the head), then the mother-child pair will be coded as an unrelated subfamily, while the male partner will be counted as a "primary individual" (and the head) in this case. On the other

hand, if the mother pays the rent, then the mother is the head, and the mother-child pair constitutes a primary family; the male partner is now called a secondary or unrelated individual. Since 1996, some such cohabitation cases have been identified in more detailed relationship variables, but the overall coding into subfamily status has remained the same.

This example suggests that in otherwise static living situations, changes in who pays the rent can interact with CPS coding rules to cause a "change" in subfamily status. We believe that in the 
absence of data constraints, most researchers would hesitate to characterize the two situations just described as different living arrangements. One might still argue that such changes in headship coding will average out under the assumption that the changes do not occur differentially in state-year cells with and without reform. While that argument is of course econometrically correct, we believe the assumption would be inappropriate in a study treating living arrangements as endogenous. We thus focus on other measures not subject to these interpretation problems.

\subsection{Outcome variables}

We construct three dummy variables indicating whether the child $(i)$ lives with neither parent, (ii) lives with a parent who is currently unmarried, or (iii) lives with a parent who is currently married. ${ }^{12}$ We also create a dummy variable indicating whether the child lives with both a parent and a grandparent. We are not able to construct a satisfactory variable for whether the child lives with a grandparent independently of whether the child also lives with a parent. ${ }^{13}$

The top row of Table 3 shows that there are enormous racial and ethnic differences in household AFDC participation rates. More than a quarter of black children in our sample lived in households that had some AFDC income in the previous year, compared to 17 percent of Hispanics and only 6 percent of whites. The discrepancy for the pre-reform era is even more pronounced. It is particularly noteworthy that whites comprise more than 60 percent of our sample, but the theoretical effect of welfare reform for them is necessarily close to zero, given their low rates of using cash assistance. However, there is a second reason to stratify our sample by race and ethnicity: baseline living arrangements are very different for blacks, Hispanics, and whites. For example, while 57 percent of

\footnotetext{
${ }^{12}$ The CPS provides codes indicating the within-household line number of a person's parent, if that parent lives in the household. We are thus able to correctly identify whether a person lives with at least one parent. Together with the CPS's marital status variable, we can construct these three variables without relying on relationships to the household or family reference person. The definition of parent here is biological parent, adoptive parent, or step-parent; this is how the Census Bureau classifies parental relationships for the March ADF. For the 1987 and 1988 March CPS files, no parent line variable was included, another reason for starting our sample with the 1989 March CPS.

${ }^{13}$ CPS coding allows a child's grandparent to be identified in one of two ways: $(i)$ if the grandparent is the head of household or $(i i)$ the child's parent also lives in the household. We believe the first approach may lead to systematically miscoding children as not living with grandparents when, say, a child lives with both a grandparent and an aunt who pays the rent. We therefore restrict our attention to children living with both a parent and a grandparent, an outcome that is observable because the CPS parent line of parents may be used to establish the presence of grandparents. We will still undercount some grandparents for children whose parents are unmarried but both live in the household. In this case, one parent will be coded as unrelated to the child, and if that parent's parent lives in the household then our approach will fail to code the child's grandparent as living in the household.
} 
black children in our sample lived with an unmarried parent, only 19 percent of white children did. Such differences suggest the presence of different cultural norms and perhaps different responses to given economic conditions. It thus seems more reasonable to think that treatment effects for racial and ethnic groups differ than that they are the same.

For these reasons, we estimate results separately for blacks, Hispanics, and whites, avoiding the averaging together of zero effects for children who never use welfare with the possibly nonzero effects among children likely to be affected by reform. ${ }^{14}$ That is not to say that high-use subgroups must have large net effects, however. Different elements of reform operate in opposing directions, so the true net effect for high-use subgroups need not be greater in magnitude than the effect for whites. What we do expect is that whites cannot have large reform effects; we must be skeptical of any methodology that suggests they do.

It is important to note that unlike studies that use samples of women, we do not control for, or stratify, by education level. Clearly women in lower education groups are more likely to be affected by reform. But here, our focus is on children, who have not completed their education. A natural choice would be to use the education level of the head of household. However, if the head's identity is endogenous, then demographic characteristics of the head (e.g., education level and marital status) in households where children live could change endogenously with welfare reforms, making such variables inappropriate controls. This potential movement of children between households highlights why we focus on a sample of children, rather than a sample of women.

Column 4 of Table 3 shows that 13 percent of the observations in our sample were exposed to waivers, while more than 30 percent were exposed to TANF. Most TANF exposure occurred in states that ever had a waiver, rather than those that never had a waiver. About 80 percent of the sample lived in an MSA, while about one-fourth lived in a central city. Overall, more than two-thirds of the children lived with a married parent, 27 percent lived with an unmarried parent, and 3 percent lived with neither parent. Six percent of all children lived with both a parent and a grandparent. Statistics for black, Hispanic, and white children are provided in columns 1-3 of the table.

\footnotetext{
${ }^{14}$ In an earlier draft of this paper (Bitler et al. (2002)) we presented estimates for black central-city children. The results were qualitatively similar to those presented here for the full sample of blacks, with higher average effects reflecting the higher welfare participation rates of central-city blacks. To be robust to concerns about endogenous location decisions, we choose here to focus on all black children.
} 


\subsection{Simple before-after differences in outcomes}

One way to assess the impact of welfare reform is to compare simple means of outcome variables before and after reforms were implemented. Table 4 reports such means, together with standard errors, for the samples and subgroups on which we focus. In the table, the "Before reform, waiver state" cells report the mean and standard error of the outcome for observations in states that ever had a waiver, in the years before the waiver was implemented. The "After reform, waiver state" cells do the same for observations in these states in years after the waiver was implemented (including years during which TANF was implemented). For nonwaiver states, the before period includes all years before TANF implementation, and the after period includes all years after TANF implementation. By taking differences between the outcomes before and after welfare reformwhether waivers or TANF — we obtain crude estimates of the impact of reform on our outcomes of interest.

These simple results suggest very large changes in living arrangements for some children. Among black children, the fraction living with neither parent rises by about 3 percentage points after reform in waiver states, from 6.6 percent to 9.5 percent. About two-thirds of this net change is accounted for by a reduction in the fraction living with an unmarried parent, with the balance related to reductions in living with a married parent. A smaller increase in the fraction living with neither parent - about one percentage point - occurs with TANF implementation for black children in nonwaiver states; this is entirely accounted for by a reduction in the fraction living with an unmarried parent.

Among Hispanic children, there are increases of slightly more than a percentage point in the fraction living with neither parent in both waiver and nonwaiver states. Other changes vary greatly by waiver history: in waiver states, there is a reduction of more than 3 points in the fraction living with a married parent, with a 2 point increase in the fraction with an unmarried parent. The opposite pattern occurs in non-waiver states. It is interesting to note that the baseline unmarried parent rate is much larger in the non-waiver states - 40 percent, compared to "just" 28 percent in waiver states.

Among white children, waiver status seems to be uninformative regarding changes in living arrangements. Both sets of states saw a small increase, of about a half percentage point, in the fraction living with neither parent. Both sets also experienced a nearly 2 point increase in the 
fraction living with an unmarried parent, together with a more than 2 point decrease in the fraction living with a married parent.

Taken together, these before-after comparisons suggest that welfare reform has been associated with potentially important changes in children's living arrangements. Moreover, the pattern and magnitude of these changes varies considerably by race and ethnicity, as well as by state waiver history. While before-after comparisons are prima facie interesting, they do not establish either the presence or absence of causal effects of welfare reform on living arrangements. Economic conditions improved greatly at roughly the same time that reforms were implemented, and other, more difficult-to-measure social trends may have been operating concurrently. Such concerns imply that more careful analysis is warranted in order to control for as many confounding factors as possible. We next describe our empirical approach to dealing with these issues.

\section{Empirical Model}

The standard approach in much of the literature discussed above is to use pooled cross-sections and run regressions of outcome measures on demographic covariates, state-level controls, policy variables, and state and year fixed effects. We follow this basic approach, estimating probits of a latent variable model having the following form:

$$
y_{i s t}=X_{i s t} \delta+L_{s t} \alpha+R_{s t} \beta+\gamma_{s}+\nu_{t}+\epsilon_{i s t},
$$

where the latent index $y_{i s t}$ indicates an outcome for individual $i$ in state $s$ in year $t$. Here, $X_{i s t}$ is a vector of demographic characteristics, including controls for the person's age and its square, as well as dummy variables indicating residence in an urban area (MSA) and a central city (as well as dummies indicating whether the CPS identifies a household's MSA or central-city status, since this information is suppressed in small areas). The vector $L_{s t}$ contains state-level labor market variables meant to control for economic opportunities in the state. These variables include current and one-year lags of unemployment and aggregate employment growth rates, as suggested by Blank (2001), as well as public assistance program variables (other than the reform variables) including the real maximum welfare benefit level for a family of three and measures of a state's Medicaid generosity. The $\gamma_{s}$ and $\nu_{t}$ terms represent state and year fixed effects. The state (year) fixed effects 
control for unobserved factors that differ across states and not over time (over time and not across states). Unobservable determinants are captured by $\epsilon_{i s t}$. All regressions and summary statistics are weighted using the March Supplement person weight. ${ }^{15}$

Our main focus is on the coefficients of $R_{s t}$, a vector of simple dummy variables indicating whether or not the given reform-waiver or TANF-is in place in state $s$ for year $t$. Following the convention in the literature, we code a waiver as being in place only if it was "major", in the sense of involving a significant deviation from the state's AFDC program, and if it was in place statewide. For TANF, we construct a dummy variable indicating whether the state's TANF plan had been implemented. In general, we code states as having implemented a policy in a given month if the policy was implemented by the last day of the previous month. Since our data are collected in March, we code the policy as being in place in a given year if it was in place by the last day of February of that year. Our primary data source for the dating of state reforms is a set of tables available on the website of the Assistant Secretary for Planning and Evaluation (ASPE) for the Department of Health and Human Services. ${ }^{16}$

Some observers object that the simple dummy-variable approach taken here assumes that reform effects occur instantaneously at the time of implementation. However, this objection is on target only if one assumes that reform's effects are constant (over time and across states). This assumption would be unreasonable even if instantaneous effects could be presumed. Detailed aspects of state reforms and economic conditions can be difficult to observe. Moreover, there is no reason to think that different demographic groups will respond to the same reforms in the same manner. Given all this, we strongly believe that the coefficients on $R_{s t}$ should be interpreted as averages of heterogeneous treatment effects over the post-reform period.

Given this interpretation of the coefficients in (1), using year fixed effects introduces an important problem. Since TANF implementation varies across states only for the period between September 1996-January 1998, no state implements by the March 1996 survey, and every state has implemented by the March 1998 survey. Hence, the use of year effects removes all identifying variation from the post-1997 data. As a consequence, other things constant, our TANF effects are

\footnotetext{
${ }^{15}$ Results are robust to alternative weighting schemes.

${ }^{16}$ Specifically, a waiver is considered "major" only if it related to one of the following policies: termination time limits, work exemptions, sanctions, increased earnings disregards, family caps, or work requirement time limits. The URL for the relevant ASPE website is http://aspe.hhs.gov/hsp/Waiver-Policies99/policy_CEA.htm. More specific details regarding our construction of reform variables are available on request in a data appendix.
} 
identified entirely from cross-sectional variation in the March 1997 survey. Under a constant-overtime assumption on the (average) effects of reform, this introduces no difficulty: having estimated the effect for one year, we would know it for all years. On the other hand, if one insists that over-time heterogeneity in the cross-sectional treatment effect be unrestricted, then our estimates identify the impact of TANF for 1997, and for no other year. This fundamental identification problem is discussed in detail in Bitler et al. (2003, (Papers and Proceedings)).

This problem raises serious obstacles to estimating TANF effects using non-experimental data, and adding later years of data will do nothing to solve it. In the end, one must either assume dynamically constant treatment effects, assume that underlying trends can be parameterized $a$ priori, find convincing control groups, or accept that only one year's treatment effect is identified. It seems unlikely that treatment effects would stay constant while reform takes root. Parameterizing time trends requires a significant leap of faith at a time when both unmeasured economic conditions and social norms concerning welfare and single-parenthood may have been changing in unknown ways. Convincing control groups are particularly difficult to find when focusing on children's living arrangements. On the one hand, one cannot condition on parental characteristics (e.g., educational attainment), since the presence of parents is endogenous. On the other hand, the most salient fixed characteristics for children are their race and ethnicity. While we have shown that welfare use varies enormously along these dimensions, so do baseline living arrangements. As a consequence, we think that convincing comparison groups are an unlikely path. Thus, we are left with the most conservative interpretation of the TANF estimates: that they represent plausibly well-identified average treatment effects for 1997 among states that implemented reform before 1997.

Fortunately, the greater variation in date of waiver implementation, together with the fact that some states never implemented a waiver, means this issue is not a concern for identifying average waiver effects among waiver states. The top panel of Table 1 reports the first year for which we coded observations in each state as subject to a waiver. The table also lists the states that never implemented major statewide waivers according to ASPE. It is clear from the table, as well as from the previous literature, that there is substantial variation in the implementation of state waivers across states and time. We may thus regard the estimated waiver coefficients as average treatment effects among waiver states (the usual "treatment on the treated" parameter), during years when their waivers were implemented. 
Because we treat waivers and TANF implementation distinctly, our econometric models involve a "dual treatment" specification. States may be classified into four groups at any given time: (i) those who currently have neither an AFDC waiver nor TANF implemented; (ii) those who currently have AFDC waivers implemented; (iii) those who currently have TANF implemented and at some point in the past implemented an AFDC waiver; and (iv) those who currently have TANF implemented and never implemented a waiver.

Our focus will generally be on the least restrictive specification of reform effects, which simply includes dummy variables for three of these four categories. This approach allows distinct effects for each of the three reform regimes. We have chosen to make our baseline group be category $(i)$, state-year combinations for which neither reform is in place. The three coefficients are presented in stylized cases in Figures 1a and 1b. Each figure presents the trend in some outcome variable over time and marks the point where the waiver is implemented (if applicable) and when TANF is implemented. Figure 1a presents the case of a state that had a waiver and Figure 1b presents the case of a state that did not have a waiver. Our key coefficients are $\beta_{W}$, measuring the impact of waivers, $\beta_{T E}$, measuring the impact of TANF for a state that had an earlier waiver, and $\beta_{T N}$, measuring the impact of TANF for a state that did not have a waiver. Each of these coefficients is measured relative to the baseline period. In our empirical specifications, the waiver dummy is always set to 0 once the state's TANF program has been implemented. Thus, the coefficients on these variables are all comparable to each other (i.e., none of them must be added together to get the total effect of the given reform).

Lastly, we adjust our standard errors to allow arbitrary correlation within state-by-year cells. Hence, our precision is not spuriously driven by the fact that we use microdata, while the policy variation occurs at the state-by-year level. ${ }^{17}$ An additional concern may arise in light of recent work by Kezdi (2002) and Bertrand, Duflo \& Mullainathan (2002). They show that when there is serial correlation, as may be common in the CPS, methods like ours that use variation in state policy reforms may lead to greatly understated standard errors unless within-state autocorrelation

\footnotetext{
${ }^{17}$ An additional issue concerning standard errors apparently arises because we use microdata, i.e., we include a separate observation for each child in a household. One might worry that we thus inappropriately treat multiple children from the same household as iid observations despite the obvious correlation of unobservables for children in the same household. In fact, when the left hand side variables do not vary within households, this issue is not a problem at all: since we weight the regressions and there are few RHS variables that vary within-household (age and race/ethnicity being the lone exceptions), these specifications are nearly equivalent to running household-level regressions using weights equal to the sum of the individual observations' weights.
} 
is accounted for. In section 7, we explore extensions of the basic model that include state-specific trends to soak up unobservables that change over time at the state level, which should reduce the degree of residual serial correlation. We also re-estimated our covariance matrices using state-level clustering, as suggested by both Kezdi (2002) and Bertrand et al. (2002). There were no apparent changes in the significance of our variables of interest.

\section{Main Results}

We report the main results in this section. All tables present probit marginal effects of switching on the reform dummies. A slight complication arises here because packaged marginal effects routines typically calculate the marginal effect for dummy variable $D$ by evaluating the probit function either at some index value (like the sample mean of $X \hat{\beta}$ ) or by averaging the estimated individualspecific impact of switching $D$ from 0 to 1 over the population while holding all non- $D$ variables at their sample means. But with multiple treatments, the relevant baseline involves setting all reform dummy variables to 0 rather than to their means. To address this fact, we first calculate each individual's estimated baseline probit value as the estimate with all reform dummies set to 0 . We then switch on the given reform variable (i.e., the waiver dummy or either TANF dummy) and calculate the estimated probit value. The difference between this estimated treated value and the estimated baseline is then the individual's estimated treatment effect. These individual estimates are then averaged over the relevant subpopulation to obtain the figures we actually report. Standard errors are estimated using the delta method. ${ }^{18}$ We report only the coefficients on the welfare reform variables. However, as discussed above, each of the models also includes controls for age of the child and its square, MSA status, central-city status, state labor market conditions, state public assistance programs (other than reform variables), and state and year fixed effects.

Table 5 presents estimates for black children imposing the constraint that TANF effects are homogeneous across states that ever and never had waivers $\left(\beta_{T E}=\beta_{T N}\right)$. The top panel, which presents the estimates for the children's sample, suggest that reform is associated with significant

effects on living arrangements. For example, waivers raised the fraction of black children living with neither parent by 2.8 percentage points, similar to the simple pre-post comparison reported in

${ }^{18}$ Stata code to implement this routine via the command margf $x$ is available at
http://glue.umd.edu/gelbach/stata/ado/index.html.


Table 4. This impact is (more than) entirely accounted for by a 3.6-point reduction in the fraction of black children living with an unmarried parent, and there is no net change in the fraction living with a married parent. Waivers also appear to be unrelated to the incidence of three-generation households. TANF is also associated with a large increase - about twice the waiver effect - in the fraction of children living with neither parent. This impact comes from reductions in the rate of living with an unmarried parent as well as a married parent (though neither of these effects is itself statistically significant). Unlike waivers, TANF is associated with significant reductions-4 percentage points - in the likelihood that a child lives with both a parent and grandparent.

In Table 6, we continue to focus on black children, while relaxing the constraint on the TANF effects. Thus we estimate three distinct treatment effects: one each for any major waiver $\left(\beta_{W}\right)$, TANF implementation in a state that had a waiver $\left(\beta_{T E}\right)$, and TANF implementation in a state without a waiver $\left(\beta_{T N}\right)$. The results show nontrivial heterogeneity across waiver history in the neither-parent impact of TANF, though for the other outcomes the impact of TANF is generally similar across state waiver histories.

The results presented in Table 6 show consistent, sometimes statistically significant, and substantively important effects of reform on black children's living arrangements. Some of the findings are consistent with the stated goals of reform, while others are not. The first column shows that all three measures of welfare reform are associated with statistically significant and large increases in the probability of living with neither parent. Potential causes for this finding are a child's moving in with a grandparent or other relative without her mother or the mother's leaving the household without the child. The increases range from 3.4 percentage points for waivers, to 7.3 percentage points for TANF in states that had a waiver. We can reject that the TANF effects are equal at the 0.04 level.

For the neither-parent outcome, the magnitudes of the TANF point estimates are large compared to the low baseline rate. For example, TANF in waiver states led to a doubling of the fraction of black children living with neither parent. One might worry that these estimated effects are "too large" - after all, it is rare in social science research to find such large effects of policy on behavior. We think this concern is misplaced for three reasons. First, while our probit results do suggest that the contribution of reforms is greater than the simple before-and-after difference of means, the large increase in the fraction of black children living with neither parent does show up clearly in the 
raw means reported in Table 4. Second, while the relative effects here are very large, the number of children affected is comparatively small as a fraction of all children: black children represent fewer than 16 percent of all children, so that even an increase of 7 percentage points in the number of black children living with neither parent would affect less than 1.2 percent of all children.

In general, drawing welfare conclusions can be difficult when considering changes in living arrangements, and the neither-parent results are a good case in point. One might surmise that the children newly living with neither parents have left very low-income, welfare-dependent households headed by a low-income parent, entering households headed by other relatives with higher incomes. At least from a financial perspective, these children could be better off. To investigate this hypothesis, we estimated two separate probits, for which the dependent variables were indicators for whether the child $(i)$ lived with neither parent in a household where total income in the year before the survey was at or below the Federal poverty threshold for the appropriate number of residents and (ii) lived with neither parent in a household where total income was above the Federal poverty threshold.

The results for the neither-and-poor model imply marginal effects of 1.8, 7.3, and 5.0 percentage points for the waiver, TANF-ever, and TANF-never coefficients. All three estimates are statistically significant at the 5 percent level. For the neither-and-not-poor model, the estimated marginal effects were 1.7, 2.0, and 1.0 percentage points, with only the first estimate being statistically significant at the 10 percent level or better. Of course, we do not know the counterfactual fraction of these "neither" children who would have lived in poor households in the absence of reform. Nonetheless, we believe it is reasonable to interpret these results as providing little support for the view that reform is causing children to move into well-off households with neither parent present.

Turning to the rest of Table 6, we see that reforms are associated with decreases in the fraction of black children living with an unmarried parent, a goal often associated with reform intended to promote two-parent families. This result is significant only for waivers, though the same signed coefficient is present for both TANF variables. The coefficient estimates in the third column show that waivers are associated with no change in the fraction of black children living with a married parent. TANF is negatively associated with this outcome, though not significantly so. ${ }^{19}$

\footnotetext{
${ }^{19}$ We note that the dummy variables for neither parent, unmarried parent, and married parent are exhaustive and mutually exclusive. However, the estimated marginal effects need not sum exactly to zero because the results come from single-equation, rather than multinomial, models.
} 
Results in the last column show that the likelihood of a child living with both a parent and grandparent is unaffected by waivers. However, TANF is associated with significant reductions of four percentage points in both waiver and non-waiver states. To see how this effect is associated with household poverty, we estimated a probit in which the dependent variable is a dummy equal to 1 when a black child lives in a poor three-generation household. We find no significant effects on this outcome. However, when we change the dependent variable to be 1 for being in a nonpoor three-generation household, we find statistically significant negative marginal effects of about 3 percentage points. This suggests that the net reduction in three-generation households occurs primarily among relatively better-off black children. In order to investigate whether measures of grandparent co-residence used in the literature track our findings, we estimated models of living with a grandparent who is the householder and not living with a parent (not reported in the tables). For black children, waivers are associated with a 2.1 percentage point increase in the likelihood of living with a grandparent householder and no parent, and TANF in waiver states is as a 4.3 percentage point incease in this probability.

We next move to Table 7, in which we explore how welfare reform impacts Hispanics. The results show that welfare waivers led to a statistically significant reduction in the propensity of Hispanic children to live with an unmarried parent, and a roughly equivalent increase in the propensity to live with a married parent. The effects are substantial, leading to changes of between 6 and 10 percent over baseline. TANF effects for these outcomes are smaller and statistically insignificant. The results in the first column show that unlike its impacts on black children, there is no evidence that welfare reform leads to increases in the propensity of Hispanic children to live with neither parent. Results in the final column also show no evidence of an association between welfare reform and the rate of co-residence with both a parent and a grandparent.

To complete the picture, we report in Table 8 estimates from a sample of white children. Given the large sample sizes involved, these results are estimated with a great deal of precision. Nonetheless, the estimates universally suggest no impact of reform on living arrangements for either children or women. We view this as encouraging given that only 6 percent of white children live in households that had any AFDC income in the year before the survey. 


\section{Extensions}

To gauge the robustness of our findings, we consider in this section a number of extensions to our basic models. Full tables of results for these extensions are available on request; we provide a brief summary of them here.

First, we add state-specific linear time time trends to the basic model. To do this, we can model the unobservable term in equation (1) as $\epsilon_{i s t}=\theta_{s} t+u_{i s t}$. The state-specific coefficient $\theta_{s}$ captures factors that evolve differentially across states and may be correlated with reform implementation. For blacks, adding the trends does not affect the point estimates noticeably, though it does attenuate the significance level below conventional levels for the unmarried-parent waiver coefficient and the three-generation-household TANF-ever-waiver coefficient. For Hispanics, the point estimates are again essentially unchanged, though no coefficients are significant now. For whites, the point estimates remain similar, though TANF in nonwaiver states now is associated with a statistically significant increase of 1.6 percentage points in the frequency of living in a three-generation household.

Second, we investigated the possible policy endogeneity by including leads of welfare reform variables. Leads have been used in previous work to capture either announcement effects or the possibility that reforms are implemented partly because of changes in the dependent variable. Alternatively, lead variables might pick up effects of non-statewide pilot or partial reforms. To address these possibilities, we added a separate one-year lead for each reform dummy to our probit specifications. For black children, adding the leads results in larger estimated reform effects on the unmarried-parent outcome. The waiver effect is now -5 percentage points (and still significant) rather than -4 points, while the estimate for TANF in waiver states rises from an insignificant -4 percentage points in Table 6 to a significant -10.5 percentage points. All three-generation coefficients are now insignificant as well.

Among Hispanic children, estimates with the leads imply a significant TANF-induced increase of about 4 percentage points in the fraction living with neither parent (the estimates are similar regardless of waiver history). The waiver effect on living with an unmarried parent is now slightly smaller (-2.7 percentage points rather than -3.1) and no longer significant. For white children, all four TANF coefficients for the unmarried-parent and married-parent outcomes are now significant. The estimates for living with an unmarried parent imply a 3 to 4 percentage point increase, while 
the estimates for living with a married parent imply a 3 to 4 percentage point decrease. Given the very low baseline welfare participation rate of white children, these effects seem too big to be plausible; viewing the white children as a specification check would suggest rejection of all the leads results.

Third, we include variables capturing specific features of welfare reform plans such as those discussed in Table 2. Specifically, we constructed dummy variables equal to one if: $(i)$ a state's time limits result in termination or only reduction of benefits, $(i i)$ the state imposes sanctions that result in termination of benefits, (iii) the state has eliminated the 100-hour rule governing eligibility for the AFDC Unemployed-Parent program, (iv) the state has a family cap policy preventing benefits from rising when a new child is born, and $(v)$ the state has a rule requiring that minor parents reside with adults (relatives or otherwise) in order to receive welfare benefits. We also constructed a monthly cutoff income variable, which is equal to the monthly amount of income at which a welfare participant would lose her income eligibility for assistance. This is a function of the maximum benefit, the flat disregard, and the benefit reduction rate and represents the expanded earnings disregards that many states have implemented. Each of these detailed reform variables are constructed for each state in its pre-reform, waiver (if applicable), and TANF periods. ${ }^{20}$

We explored many specifications using these detailed reform variables. In each specification we included the main reform dummies (e.g., any waiver) along with interactions of the main reform dummies and the specific reform variable. This allows for the effects of each detailed policy to vary with reform regime, and for the testing of the importance of an aggregate reform effect. In the most extensive model we include 22 reform variables - one main dummy and six detailed reform variables for each of the three implementation regimes, plus the main cutoff variable. In general, there is no shortage of statistically significant estimates. However, we do not believe the detailed results suggest any over-arching story concerning our earlier results. In some cases, the results appear to be internally consistent and informative. For example, in the black children sample, we find that time limits implemented through waivers are associated with an increase in the probability of living with neither parent and a decrease in the probability of living with an unmarried parent.

\footnotetext{
${ }^{20}$ The main sources for this data are two documents from the Assistant Secretary for Planning and Evaluation (ASPE), available at http://aspe.hhs.gov/hsp/Waiver-Policies99/policy_CEA.htm and http://aspe.hhs.gov/hsp/isp/waiver2/title.htm. These variables are discussed in our working paper (Bitler et al. (2002)), and a detailed data appendix available upon request.
} 
This could occur if time limits cause women losing benefits to leave their children with relatives. However, the results are difficult to rationalize in many other cases. For example, time limits under TANF in former waiver states are negatively and significantly related related to the probability of living with neither parent among Hispanics, the opposite of what one would expect.

We also estimated models examining a subset (one or two) of the detailed reforms, such as termination time limits and sanctions. These models quite consistently showed that the main reform effect dominates - the marginal effect of any specific policy element typically is small and statistically insignificant.

Our systematic and exhaustive exploration of detailed aspects of reform leads us to conclude that we are unlikely to uncover the specific policies that lead to the changes in living arrangements of children. There are many possible reasons for this finding. First, despite the fact that these specific reforms are probably the most frequently mentioned in welfare reform discussions, states

have implemented many others. ${ }^{21}$ Second, and more importantly, we have no way of measuring how strictly or uniformly states enforce the various rules, nor do we have information regarding states' use of exemptions allowed under PRWORA. In at least some cases, states have emphasized caseworker discretion with individual cases as a part of their programs. Thus, it seems likely that substantial unobserved heterogeneity in state policies remains. This heterogeneity will cause bias in estimated effects of specific policies within welfare-reform regimes. One advantage of the gross-treatment approach is that it is robust to this sort of bias, since only gross, average effects are estimated. Lastly, our inability to attribute the main findings of the previous sections to any specific reform characteristics is consistent with Bell (2001), as discussed in section 2.

\section{Conclusion}

The 1990s ushered in a new era for welfare programs. The U.S. has moved away from public assistance as an entitlement, focusing instead on "temporary assistance for needy families." In this paper, we examine the impacts of reform on parental co-residence status for children. By all accounts, living arrangements are an important factor in child well-being. Moreover, influencing living arrangements was an explicitly stated goal of welfare reformers. We examine two sources of

\footnotetext{
${ }^{21}$ For example, a RAND report (Williamson, Jackson \& Klerman (1997)) attempting to catalog them all only through 1997 runs nearly 100 pages.
} 
reform, state welfare waivers in the 1990s and state implementation of PRWORA. Using samples of children from the CPS, we estimate pooled cross-sectional models where the effects of reform are identified from differences in timing of reforms across states.

Our results show some important effects for children's co-residence with parents. For example, we find that significantly more black children are living with neither parent. Interestingly, we find different patterns among Hispanics from those among blacks. While there is no evidence of an increase in the fraction of Hispanic children living with neither parent, there is a marked increase in the fraction of these children living with a married parent.

These findings suggest several conclusions. First, welfare reform has had large effects on some important measures of living arrangements among subgroups where which one would expect reform effects to be concentrated. Second, those effects are neither entirely aligned with the stated goals of reform nor entirely contrary to these goals. Third, there seems to be considerable treatment heterogeneity concerning both subpopulations and whether reforms were implemented as waivers, as TANF in states that had waivers, or as TANF in states that did not. Fourth, given the many dimensions along which state-level policies have changed, we may never be able to understand which specific features of welfare reform led to the measured impacts. With so many kinds of reforms and a "laboratory" of only 50 states, any particular set of reforms may simply proxy for unmeasured differences across states rather than true policy responses.

\section{References}

Acs, G. \& Nelson, S. (2001), "Honey, I'm home." Changes in living arrangements in the late 1990s, Working Paper B-38, Urban Institute.

Bell, S. H. (2001), Why are welfare caseloads falling?, Working Paper DP 01-02, Urban Institute.

Bertrand, M., Duflo, E. \& Mullainathan, S. (2002), How much should we trust differences-indifferences estimates?, Working Paper 8841, NBER.

Bitler, M. P., Gelbach, J. B. \& Hoynes, H. W. (2002), The impact of welfare reform on living arrangements, Working Paper 8784, NBER.

Bitler, M. P., Gelbach, J. B. \& Hoynes, H. W. (2003, (Papers and Proceedings)), 'Some evidence on race, welfare reform and household income', American Economic Review 93(2), 293-8.

Blank, R. (2001), 'What causes public assistance caseloads to grow?', Journal of Human Resources 36(1), 85-118. 
Bloom, D., Scrivener, S., Michalopoulos, C., Morris, P., Hendra, R., Adams-Ciardullo, D. \& Walter, J. (2002), Jobs First: Final Report on Connecticut's Welfare Reform Initiative, Manpower Demonstration Research Corporation, New York, NY.

Casper, L. M. \& Bryson, K. R. (1998), Co-resident grandparents and their grandchildren: Grandparent maintained families, Working Paper No. 26, Population Division, U.S. Census Bureau.

CEA (1997), Explaining the decline in welfare receipt 1993-1996, Working paper, Executive Office of the President of the United States.

CEA (1999), Economic expansion, welfare reform, and the decline in welfare caseloads, an update, Working paper, Executive Office of the President of the United States.

Cox, A. G. \& Pebley, A. R. (1999), Grandparent care and welfare: Assessing the impact of public policy on split and three generation families, Working Paper DRU-2166-NICHD/NIA, RAND Labor and Population Working Paper Series.

DeLeire, T. C. \& Kalil, A. (2002), 'Good things come in threes: Single-parent multigenerational family structure and adolescent adjustment', Demography 39(2), 393-412.

Duncan, G. \& Chase-Lansdale, P. L. (2001), Welfare reform and child well-being, in R. Blank \& R. T. Haskins, eds, 'The New World of Welfare', Brookings Institution Press, Washington, D.C., pp. 391-417.

Dupree, A. \& Primus, W. (2001), Declining share of children lived with single mothers in the late 1990s, Working Paper 01-117, Center on Budget and Policy Priorities.

Dyer, W. T. \& Fairlie, R. W. (2001), Do family caps reduce out-of-wedlock births? Evidence from Arkansas, Georgia, Indiana, New Jersey and Virginia. Typescript.

Ehrle, J., Geen, R. \& Clark, R. (2001), Children cared for by relatives: Who are they and how are they faring?, Working Paper B-28, Urban Institute.

Farrell, M., Fishman, M., Laud, S. \& Allen, V. (2000), Understanding the AFDC/TANF child-only caseload: Policies, composition and characteristics in three states, Working Paper Prepared for Assistant Secretary for Planning and Evaluation, U.S. DHHS, Contract Number 100-96-001, Task Order 7, The Lewin Group.

Fitzgerald, J. M. \& Ribar, D. C. (2003), Transitions in welfare participation and female headship, Working Paper DP 895, IZA.

Grogger, J. (2003), Welfare transitions in the 1990s: The economy, welfare policy, and the EITC. Typescript.

Grogger, J. \& Michalopoulos, C. (2003), 'Welfare dynamics under time limits', Journal of Political Economy 111(3), 530-54.

Haider, S. \& Klerman, J. (Forthcoming), 'A stock-flow analysis of the welfare caseload', Journal of Human Resources . 
Horvath-Rose, A. \& Peters, H. E. (2001), Welfare waivers and non-marital childbearing, in G. Duncan \& P. L. Chase-Lansdale, eds, 'For Better and For Worse: Welfare Reform and the WellBeing of Children and Families', Russell Sage Foundation, New York.

Hu, W.-Y. (2001), 'Welfare and family stability: Do benefits affect when children leave the nest?', Journal of Human Resources 36(2), 274-303.

Kaestner, R. \& Kaushal, N. (Forthcoming), 'Immigrant and native responses to welfare reform', Journal of Population Economics .

Kearney, M. S. (Forthcoming), 'Is there an effect of incremental welfare benefits on fertility behavior? A look at the family cap', Journal of Human Resources .

Kezdi, G. (2002), Robust standard error estimation in fixed-effects panel models. University of Michigan, Typescript.

Lewis, J. (2002), The effects of welfare reform on economic outcomes of low-education men. Typescript, University of Maryland.

London, R. A. (1998), 'Trends in single mothers' living arrangements from 1970 to 1995: Correcting the Current Population Survey', Demography 35(1), 125-31.

Meyer, B. D. \& Rosenbaum, D. T. (2000), 'Making single mothers work: Recent tax and welfare policy and its effects', National Tax Journal 53(4 Part II), 1027-61.

Moffitt, R. (1999), The effect of pre-PRWORA waivers on AFDC caseloads and female earnings, income, and labor force behavior. Typescript.

Moffitt, R. \& Ploeg, M. V., eds (2001), Evaluating Welfare Reform in an Era of Transition, National Research Council, Washington, D.C.

Moffitt, R. \& Stevens, D. (2000), Changing caseloads: Macro influences and micro composition. Typescript.

Paxson, C. \& Waldfogel, J. (2003), 'Welfare reforms, family resources, and child maltreatment', Journal of Policy and Management 22(1), 85-113.

Ribar, D. C. (2002), Transitions from welfare and the employment prospects of low-skill workers. Typescript.

Schoeni, R. F. \& Blank, R. M. (2000), What has welfare reform accomplished? Impacts on welfare participation, employment, income, poverty, and family structure, Working Paper 7627, NBER.

Susin, S. \& Adler, L. (2002), Welfare reform and the living arrangements of single mothers. Typescript.

U.S. House of Representatives Committee on Ways and Means (2000), Background Materials and Data on Programs Within the Jurisdiction of the Committe on Ways and Means, U.S. Government Printing Office, Washington. 
Wallace, G. \& Blank, R. M. (1999), What goes up must come down? Explaining recent changes in public assistance caseloads, in S. H. Danziger, ed., 'Economic Conditions and Welfare Reform', W. E. Upjohn Institute, Kalamazoo, MI.

Williamson, S., Jackson, C. A. \& Klerman, J. A. (1997), Welfare waivers state-specific descriptions, Working Paper DRU-1530-NIH/NICHD, RAND.

Ziliak, J. P., Figlio, D. N., Davis, E. E. \& Connolly, L. S. (2000), 'Accounting for the decline in AFDC caseloads: Welfare reform or economic growth?', Journal of Human Resources 35(3), 570-586. 
Figure 1a: Treatment Effects When State has Waiver

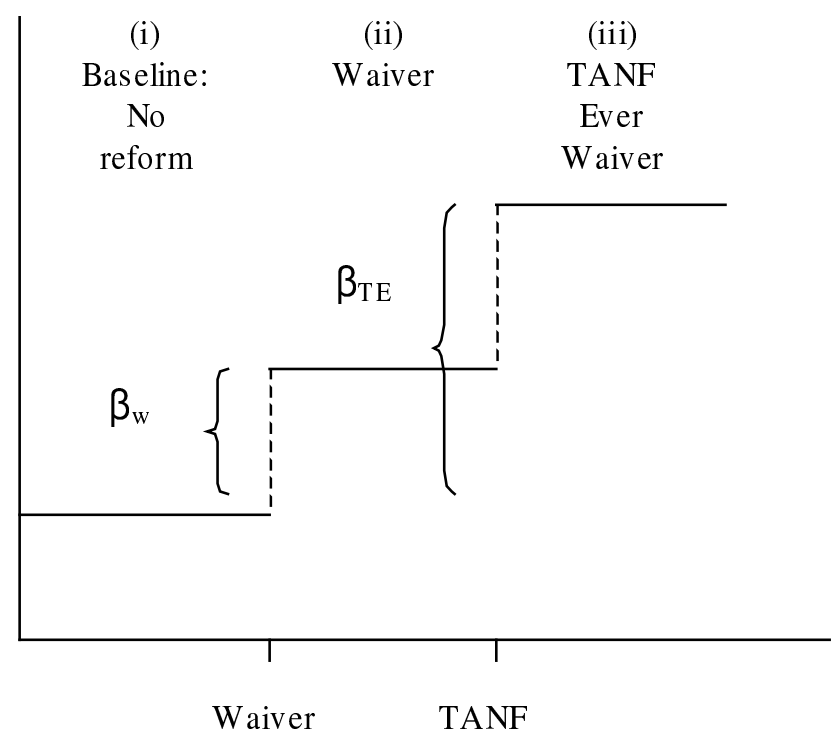

Figure 1b: Treatment Effects with No State Waiver

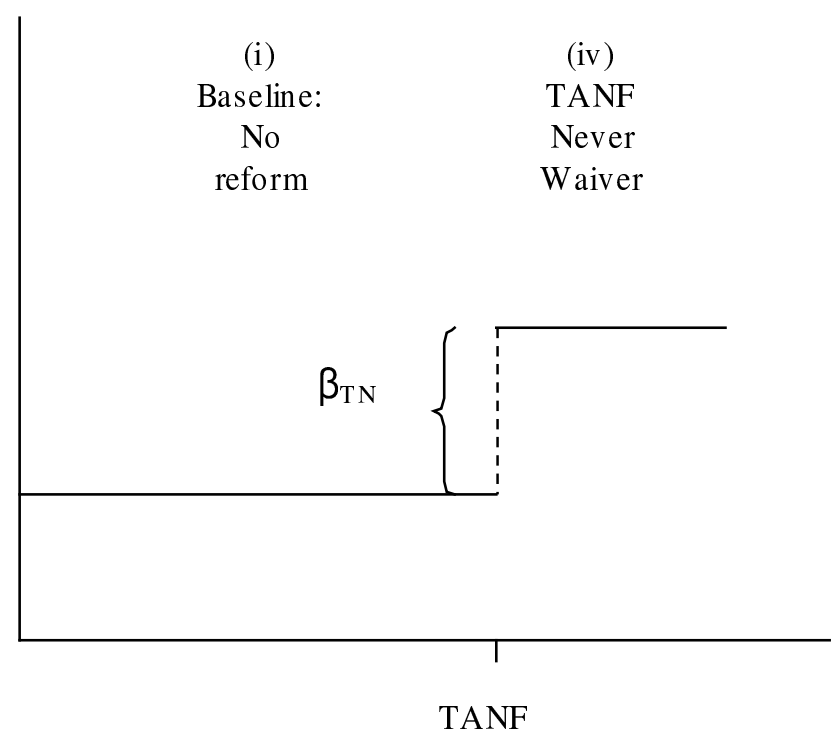


Table 1: State implementation of AFDC waivers and TANF programs, by March 1

\begin{tabular}{|c|c|c|c|c|c|c|}
\hline & 1093 & 1094 & Ever had a & aiver: & & Never had \\
\hline First & $\frac{1993}{\text { California }}$ & $\underline{1994}$ & $\frac{1995}{\text { Arkansas }}$ & $\frac{1996}{\text { Arizona }}$ & $\frac{1997}{H 9}$ & Waiver \\
\hline Year & Michigan & Illinois & South Dakota & ArIonnecticut & & Alabama \\
\hline for which & New Jersey & Iowa & Vermont & Delaware & & Kansas \\
\hline Major & Oregon & & & Indiana & & Kentucky \\
\hline Waiver & Utah & & & Massachusetts & & Louisiana \\
\hline Implemented & & & & Mississippi & & Maine \\
\hline by March 1 & & & & Missouri & & Nevada \\
\hline & & & & Montana & & New Hampshire \\
\hline & & & & Virginia & & Oklahoma \\
\hline & & & & Washington & & South Carolina \\
\hline & & & & West Virginia & & Wyoming \\
\hline & & & & Wisconsin & & Alaska \\
\hline & & & & & & Colorado \\
\hline & & & & & & $\mathrm{DC}$ \\
\hline & & & & & & Idaho \\
\hline & & & & & & Minnesota \\
\hline & & & & & & New Mexico \\
\hline & & & & & & New York \\
\hline & & & & & & North Dakota \\
\hline & & & & & & Pennsylvania \\
\hline & & & & & & Rhode Island \\
\hline & & & & & $\underline{1997}$ & $\underline{1998}$ \\
\hline First & & & & & Alabama & Alaska \\
\hline Year & & & & & Florida & Colorado \\
\hline for which & & & & & Kansas & $\mathrm{DC}$ \\
\hline TANF & & & & & Kentucky & Idaho \\
\hline Implemented & & & & & Louisiana & Minnesota \\
\hline by March 1 & & & & & Maine & New Mexico \\
\hline & & & & & Nevada & New York \\
\hline & & & & & New Hampshire & North Dakota \\
\hline & & & & & Oklahoma & Pennsylvania \\
\hline & & & & & South Carolina & Rhode Island \\
\hline & & & & & Wyoming & Arkansas \\
\hline & & & & & Arizona & California \\
\hline & & & & & Connecticut & Delaware \\
\hline & & & & & Georgia & Hawaii \\
\hline & & & & & Indiana & Illinois \\
\hline & & & & & Iowa & Mississippi \\
\hline & & & & & Maryland & New Jersey \\
\hline & & & & & Massachusetts & Wisconsin \\
\hline & & & & & Michigan & \\
\hline & & & & & Missouri & \\
\hline & & & & & Montana & \\
\hline & & & & & Nebraska & \\
\hline & & & & & North Carolina & \\
\hline & & & & & Ohio & \\
\hline & & & & & Oregon & \\
\hline & & & & & South Dakota & \\
\hline & & & & & Tennessee & \\
\hline & & & & & Texas & \\
\hline & & & & & Utah & \\
\hline & & & & & Vermont & \\
\hline & & & & & Virginia & \\
\hline & & & & & Washington & \\
\hline & & & & & West Virginia & \\
\hline
\end{tabular}


Table 2: Provisions of welfare reform and the expected effects on family structure

\begin{tabular}{|c|c|c|}
\hline & "Welfare Tightening" Reforms & "Welfare Loosening" Reforms \\
\hline \multirow[t]{11}{*}{ General Reforms } & Policy changes: & Policy changes: \\
\hline & Work requirements & Liberalized earnings disregards \\
\hline & Financial sanctions & Liberalized asset tests \\
\hline & Time limits & \\
\hline & 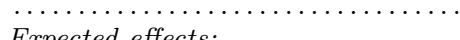 & \\
\hline & Lupeciea ejJects. & $\uparrow$ in fonalis. \\
\hline & $\uparrow$ marriage & $\downarrow$ marriage \\
\hline & $\downarrow$ nonmarital births & $\uparrow$ nonmarital births \\
\hline & More fiscal stress: & Less fiscal stress: \\
\hline & $\uparrow$ doubling-up (larger households) & $\downarrow$ doubling-up (smaller households) \\
\hline & $\uparrow$ child living without parents & $\downarrow$ child living without parents \\
\hline \multirow{7}{*}{$\begin{array}{l}\text { Family Structure } \\
\text { Specific Reforms }\end{array}$} & Policy changes: & Policy changes: \\
\hline & Family caps & $\begin{array}{l}\text { Expanded eligibility } \\
\text { for two-parent families }\end{array}$ \\
\hline & $\begin{array}{l}\text { Residency requirements for } \\
\text { unmarried teens }\end{array}$ & \\
\hline & Expected effects: & Expected effects: \\
\hline & $\downarrow$ welfare fertility & $\uparrow$ marriage \\
\hline & $\uparrow 3$ generation households & $\downarrow$ divorce \\
\hline & & More men in the household \\
\hline
\end{tabular}

Table 3: Summary statistics, by race and ethnicity

\begin{tabular}{|c|c|c|c|c|}
\hline & Blacks & Hispanics & Whites & Pooled sample \\
\hline HH had AFDC income last year & $\begin{array}{l}0.27 \\
(0.00)\end{array}$ & $\begin{array}{l}\overline{0.17} \\
(0.00)\end{array}$ & $\begin{array}{l}0.06 \\
(0.00)\end{array}$ & $\begin{array}{l}0.11 \\
(0.00)\end{array}$ \\
\hline Waiver implemented & $\begin{array}{l}0.11 \\
(0.00)\end{array}$ & $\begin{array}{l}0.19 \\
(0.00)\end{array}$ & $\begin{array}{l}0.12 \\
(0.00)\end{array}$ & $\begin{array}{l}0.13 \\
(0.00)\end{array}$ \\
\hline TANF implemented, ever had a waiver & $\begin{array}{l}0.21 \\
(0.00)\end{array}$ & $\begin{array}{l}0.26 \\
(0.00)\end{array}$ & $\begin{array}{l}0.21 \\
(0.00)\end{array}$ & $\begin{array}{l}0.22 \\
(0.00)\end{array}$ \\
\hline TANF implemented, never had a waiver & $\begin{array}{l}0.10 \\
(0.00)\end{array}$ & $\begin{array}{l}0.07 \\
(0.00)\end{array}$ & $\begin{array}{l}0.09 \\
(0.00)\end{array}$ & $\begin{array}{l}0.09 \\
(0.00)\end{array}$ \\
\hline Child lives with neither parent & $\begin{array}{l}0.08 \\
(0.00)\end{array}$ & $\begin{array}{l}0.04 \\
(0.00)\end{array}$ & $\begin{array}{l}0.02 \\
(0.00)\end{array}$ & $\begin{array}{l}0.03 \\
(0.00)\end{array}$ \\
\hline Child lives with unmarried parent & $\begin{array}{l}0.57 \\
(0.00)\end{array}$ & $\begin{array}{l}0.32 \\
(0.00)\end{array}$ & $\begin{array}{l}0.19 \\
(0.00)\end{array}$ & $\begin{array}{l}0.27 \\
(0.00)\end{array}$ \\
\hline Child lives with married parent & $\begin{array}{l}0.35 \\
(0.00)\end{array}$ & $\begin{array}{l}0.65 \\
(0.00)\end{array}$ & $\begin{array}{l}0.79 \\
(0.00)\end{array}$ & $\begin{array}{l}0.70 \\
(0.00)\end{array}$ \\
\hline Child lives with parent and grandparent & $\begin{array}{l}0.10 \\
(0.00)\end{array}$ & $\begin{array}{l}0.08 \\
(0.00)\end{array}$ & $\begin{array}{l}0.04 \\
(0.00)\end{array}$ & $\begin{array}{l}0.06 \\
(0.00)\end{array}$ \\
\hline Real maximum benefits for a family of three $(\$ 100)$ & $\begin{array}{l}4.45 \\
(0.01)\end{array}$ & $\begin{array}{l}5.71 \\
(0.01)\end{array}$ & $\begin{array}{l}5.16 \\
(0.01)\end{array}$ & $\begin{array}{l}5.17 \\
(0.00)\end{array}$ \\
\hline Unemployment rate & $\begin{array}{l}5.60 \\
(0.01)\end{array}$ & $\begin{array}{l}6.10 \\
(0.01)\end{array}$ & $\begin{array}{l}5.48 \\
(0.00)\end{array}$ & $\begin{array}{l}5.59 \\
(0.00)\end{array}$ \\
\hline Employment growth rate & $\begin{array}{l}1.93 \\
(0.01)\end{array}$ & $\begin{array}{l}2.06 \\
(0.01)\end{array}$ & $\begin{array}{l}1.93 \\
(0.00)\end{array}$ & $\begin{array}{l}1.95 \\
(0.00)\end{array}$ \\
\hline Living in central city & $\begin{array}{l}0.49 \\
(0.00)\end{array}$ & $\begin{array}{l}0.42 \\
(0.00)\end{array}$ & $\begin{array}{l}0.15 \\
(0.00)\end{array}$ & $\begin{array}{l}0.24 \\
(0.00)\end{array}$ \\
\hline Central city status unidentified & $\begin{array}{l}0.13 \\
(0.00)\end{array}$ & $\begin{array}{l}0.12 \\
(0.00)\end{array}$ & $\begin{array}{l}0.17 \\
(0.00)\end{array}$ & $\begin{array}{l}0.15 \\
(0.00)\end{array}$ \\
\hline Living in MSA & $\begin{array}{l}0.85 \\
(0.00)\end{array}$ & $\begin{array}{l}0.90 \\
(0.00)\end{array}$ & $\begin{array}{l}0.74 \\
(0.00)\end{array}$ & $\begin{array}{l}0.78 \\
(0.00)\end{array}$ \\
\hline MSA status unidentified & $\begin{array}{l}0.00 \\
(0.00)\end{array}$ & $\begin{array}{l}0.00 \\
(0.00)\end{array}$ & $\begin{array}{l}0.01 \\
(0.00)\end{array}$ & $\begin{array}{l}0.01 \\
(0.00)\end{array}$ \\
\hline Age & $\begin{array}{l}7.4 \\
(0.0)\end{array}$ & $\begin{array}{l}7.0 \\
(0.0)\end{array}$ & $\begin{array}{l}7.5 \\
(0.0)\end{array}$ & $\begin{array}{l}7.4 \\
(0.0)\end{array}$ \\
\hline $\mathrm{N}$ & 26,549 & 33,442 & 139,000 & 209,382 \\
\hline
\end{tabular}


Note: Tabulations from the March CPS, 1989-2000, using only respondents in households in months 1-4 of sample. All figures in top row of each cell are means. Figures in bottom row are standard deviations. All figures weighted using March psupwgt variable. See text for more information. 
Table 4: Raw means before and after reform

\begin{tabular}{|c|c|c|c|c|}
\hline & $\begin{array}{l}\text { Neither } \\
\text { Parent }\end{array}$ & $\begin{array}{l}\text { Unmarried } \\
\text { Parent }\end{array}$ & $\begin{array}{l}\text { Married } \\
\text { Parent }\end{array}$ & $\begin{array}{l}\text { Parent \& } \\
\text { Grandparent }\end{array}$ \\
\hline \multicolumn{5}{|l|}{$\underline{B l a c k}$} \\
\hline Pre-reform, had waiver & $\begin{array}{l}0.066 \\
(0.003)\end{array}$ & $\begin{array}{l}0.571 \\
(0.005)\end{array}$ & $\begin{array}{l}0.364 \\
(0.005)\end{array}$ & $\begin{array}{l}0.100 \\
(0.003)\end{array}$ \\
\hline Post-reform, had waiver & $\begin{array}{l}\mathrm{r} 0.095 \\
(0.003)\end{array}$ & $\begin{array}{l}0.555 \\
(0.005)\end{array}$ & $\begin{array}{l}0.351 \\
(0.005)\end{array}$ & $\begin{array}{l}0.100 \\
(0.003)\end{array}$ \\
\hline Pre-reform, no waiver & $\begin{array}{l}0.083 \\
(0.003)\end{array}$ & $\begin{array}{l}0.575 \\
(0.006)\end{array}$ & $\begin{array}{l}0.341 \\
(0.006)\end{array}$ & $\begin{array}{l}0.102 \\
(0.004)\end{array}$ \\
\hline Post-reform, no waiver & $\begin{array}{l}0.094 \\
(0.005)\end{array}$ & $\begin{array}{l}0.565 \\
(0.010)\end{array}$ & $\begin{array}{l}0.341 \\
(0.009)\end{array}$ & $\begin{array}{l}0.092 \\
(0.006)\end{array}$ \\
\hline \multicolumn{5}{|l|}{ Hispanic } \\
\hline 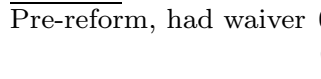 & $\begin{array}{l}0.030 \\
(0.002)\end{array}$ & $\begin{array}{l}0.281 \\
(0.005)\end{array}$ & $\begin{array}{l}0.689 \\
(0.005)\end{array}$ & $\begin{array}{l}0.079 \\
(0.003)\end{array}$ \\
\hline Post-reform, had waiver & $\begin{array}{l}\mathrm{r} 0.043 \\
(0.002)\end{array}$ & $\begin{array}{l}0.302 \\
(0.004)\end{array}$ & $\begin{array}{l}0.655 \\
(0.004)\end{array}$ & $\begin{array}{l}0.078 \\
(0.002)\end{array}$ \\
\hline Pre-reform, no waiver & $\begin{array}{l}0.036 \\
(0.003)\end{array}$ & $\begin{array}{l}0.407 \\
(0.006)\end{array}$ & $\begin{array}{l}0.557 \\
(0.007)\end{array}$ & $\begin{array}{l}0.081 \\
(0.004)\end{array}$ \\
\hline Post-reform, no waiver & $\begin{array}{l}0.050 \\
(0.004)\end{array}$ & $\begin{array}{l}0.359 \\
(0.009)\end{array}$ & $\begin{array}{l}0.591 \\
(0.010)\end{array}$ & $\begin{array}{l}0.082 \\
(0.005)\end{array}$ \\
\hline \multicolumn{5}{|l|}{ White } \\
\hline$\overline{\text { Pre-reform, had waiver }}$ & $\begin{array}{l}0.017 \\
(0.001)\end{array}$ & $\begin{array}{l}0.186 \\
(0.002)\end{array}$ & $\begin{array}{l}0.798 \\
(0.002)\end{array}$ & $\begin{array}{l}0.037 \\
(0.001)\end{array}$ \\
\hline Post-reform, had waiver & $\begin{array}{l}\mathrm{r} 0.023 \\
(0.001)\end{array}$ & $\begin{array}{l}0.203 \\
(0.002)\end{array}$ & $\begin{array}{l}0.774 \\
(0.002)\end{array}$ & $\begin{array}{l}0.043 \\
(0.001)\end{array}$ \\
\hline Pre-reform, no waiver & $\begin{array}{l}0.018 \\
(0.001)\end{array}$ & $\begin{array}{l}0.184 \\
(0.002)\end{array}$ & $\begin{array}{l}0.798 \\
(0.002)\end{array}$ & $\begin{array}{l}0.036 \\
(0.001)\end{array}$ \\
\hline Post-reform, no waiver & $\begin{array}{l}0.023 \\
(0.001)\end{array}$ & $\begin{array}{l}0.200 \\
(0.003)\end{array}$ & $\begin{array}{l}0.777 \\
(0.004)\end{array}$ & $\begin{array}{l}0.044 \\
(0.002)\end{array}$ \\
\hline \multicolumn{5}{|l|}{ Pooled } \\
\hline$\overline{\text { Pre-reform, had waiver }}$ & $\begin{array}{l}0.026 \\
(0.001)\end{array}$ & $\begin{array}{l}0.257 \\
(0.002)\end{array}$ & $\begin{array}{l}0.717 \\
(0.002)\end{array}$ & $\begin{array}{l}0.055 \\
(0.001)\end{array}$ \\
\hline Post-reform, had waiver & $\begin{array}{l}\mathrm{r} 0.037 \\
(0.001)\end{array}$ & $\begin{array}{l}0.270 \\
(0.002)\end{array}$ & $\begin{array}{l}0.693 \\
(0.002)\end{array}$ & $\begin{array}{l}0.063 \\
(0.001)\end{array}$ \\
\hline Pre-reform, no waiver & $\begin{array}{l}0.031 \\
(0.001)\end{array}$ & $\begin{array}{l}0.273 \\
(0.002)\end{array}$ & $\begin{array}{l}0.696 \\
(0.002)\end{array}$ & $\begin{array}{l}0.054 \\
(0.001)\end{array}$ \\
\hline Post-reform, no waiver & $\begin{array}{l}0.040 \\
(0.001)\end{array}$ & $\begin{array}{l}0.284 \\
(0.003)\end{array}$ & $\begin{array}{l}0.677 \\
(0.003)\end{array}$ & $\begin{array}{l}0.057 \\
(0.002)\end{array}$ \\
\hline
\end{tabular}

Note: Tabulations from the March CPS, 1989-2000, using only respondents in households in months 1-4 of sample. All figures in top row of cell are means. All figures in bottom row are standard errors. "Pre-reform" sample consists of all observations for which no reform (waiver or TANF) has been implemented. "Post-reform" sample consists of all observations for which some reform (waiver or TANF) has been implemented. All figures weighted using March psupwgt variable. See text for more information. 
Table 5: Results for black sample, TANF effects constrained to be symmetric

\begin{tabular}{|c|c|c|c|c|}
\hline \multirow[b]{2}{*}{ Any major waiver } & Neither & Unmarried & Married & $\begin{array}{l}\text { Parent \& } \\
\text { Grandparent }\end{array}$ \\
\hline & $\begin{array}{l}0.028^{* *} \\
(0.012)\end{array}$ & $\begin{array}{l}-0.036^{*} \\
(0.022)\end{array}$ & $\begin{array}{l}0.004 \\
(0.019)\end{array}$ & $\begin{array}{l}-0.003 \\
(0.011)\end{array}$ \\
\hline TANF enacted & $\begin{array}{l}0.059^{* * *} \\
(0.020)\end{array}$ & $\begin{array}{l}-0.032 \\
(0.034)\end{array}$ & $\begin{array}{l}-0.023 \\
(0.036)\end{array}$ & $\begin{array}{c}-0.041^{* *} \\
(0.019)\end{array}$ \\
\hline Pre-reform mean & 0.073 & 0.573 & 0.354 & 0.101 \\
\hline \multicolumn{5}{|c|}{$\begin{array}{l}\text { Note: }{ }^{* * *},{ }^{* *}, \text { and }{ }^{*} \text { indicate statistical significance at the } 1 \%, 5 \% \text {, and } 10 \% \text { levels, respectively. All figures are } \\
\text { marginal effects and associated standard errors calculated by averaging individual-specific marginal effects. Marginal } \\
\text { effects for each reform dummy are calculated with all other reform dummies set to 0. All specifications are weighted } \\
\text { using March CPS psupwgt variable, with robust variance calculations to account for state-by-year-level clustering. } \\
\text { Economic and welfare reform variables refer to the the survey year. Additional control variables are: age of child and } \\
\text { its square; real maximum AFDC/TANF benefits for a family of three; current and one-year lagged values of state } \\
\text { rates of unemployment and employment growth; dummies for residence in central city and MSA; dummy for central- } \\
\text { city status being censored; dummy for MSA status being censored; dummy for whether any Medicaid expansion has } \\
\text { been enacted in the state; income limit (as percentage of FPL) for pregnant women to be eligible for Medicaid; and } \\
\text { year and state dummy variables. }\end{array}$} \\
\hline
\end{tabular}


Table 6: Results for black sample, effects unconstrained

\begin{tabular}{|c|c|c|c|c|}
\hline Any major waiver & $\begin{array}{l}\frac{\text { Neither }}{0.034^{* * *}} \\
(0.012)\end{array}$ & $\begin{array}{l}\text { Unmarried } \\
-0.040^{*} \\
(0.021)\end{array}$ & $\begin{array}{l}\text { Married } \\
0.003 \\
(0.019)\end{array}$ & $\begin{array}{l}\text { Parent \& } \\
\text { Grandparent } \\
-0.002 \\
(0.012)\end{array}$ \\
\hline \multicolumn{5}{|l|}{ TANF in force: } \\
\hline$\overline{\text { Ever had waiver }}$ & $\begin{array}{l}0.073^{* * *} \\
(0.023)\end{array}$ & $\begin{array}{l}-0.040 \\
(0.035)\end{array}$ & $\begin{array}{l}-0.025 \\
(0.036)\end{array}$ & $\begin{array}{l}-0.040^{* *} \\
(0.020)\end{array}$ \\
\hline Never had waiver & $\begin{array}{l}0.042^{* *} \\
(0.019)\end{array}$ & $\begin{array}{c}-0.022 \\
(0.039)\end{array}$ & $\begin{array}{l}-0.021 \\
(0.042)\end{array}$ & $\begin{array}{l}-0.043^{* *} \\
(0.019)\end{array}$ \\
\hline Pre-reform mean & 0.073 & 0.573 & 0.354 & 0.101 \\
\hline \multicolumn{5}{|c|}{$\begin{array}{l}\text { Note: }{ }^{* * *},{ }^{* *}, \text { and }{ }^{*} \text { indicate statistical significance at the } 1 \%, 5 \% \text {, and } 10 \% \text { levels, respectively. All figures are } \\
\text { marginal effects and associated standard errors calculated by averaging individual-specific marginal effects. Marginal } \\
\text { effects for each reform dummy are calculated with all other reform dummies set to 0. All specifications are weighted } \\
\text { using March CPS psupwgt variable, with robust variance calculations to account for state-by-year-level clustering. } \\
\text { Economic and welfare reform variables refer to the the survey year. Additional control variables are: age of child and } \\
\text { its square; real maximum AFDC/TANF benefits for a family of three; current and one-year lagged values of state } \\
\text { rates of unemployment and employment growth; dummies for residence in central city and MSA; dummy for central- } \\
\text { city status being censored; dummy for MSA status being censored; dummy for whether any Medicaid expansion has } \\
\text { been enacted in the state; income limit (as percentage of FPL) for pregnant women to be eligible for Medicaid; and } \\
\text { year and state dummy variables. }\end{array}$} \\
\hline
\end{tabular}


Table 7: Results for Hispanic sample, effects unconstrained

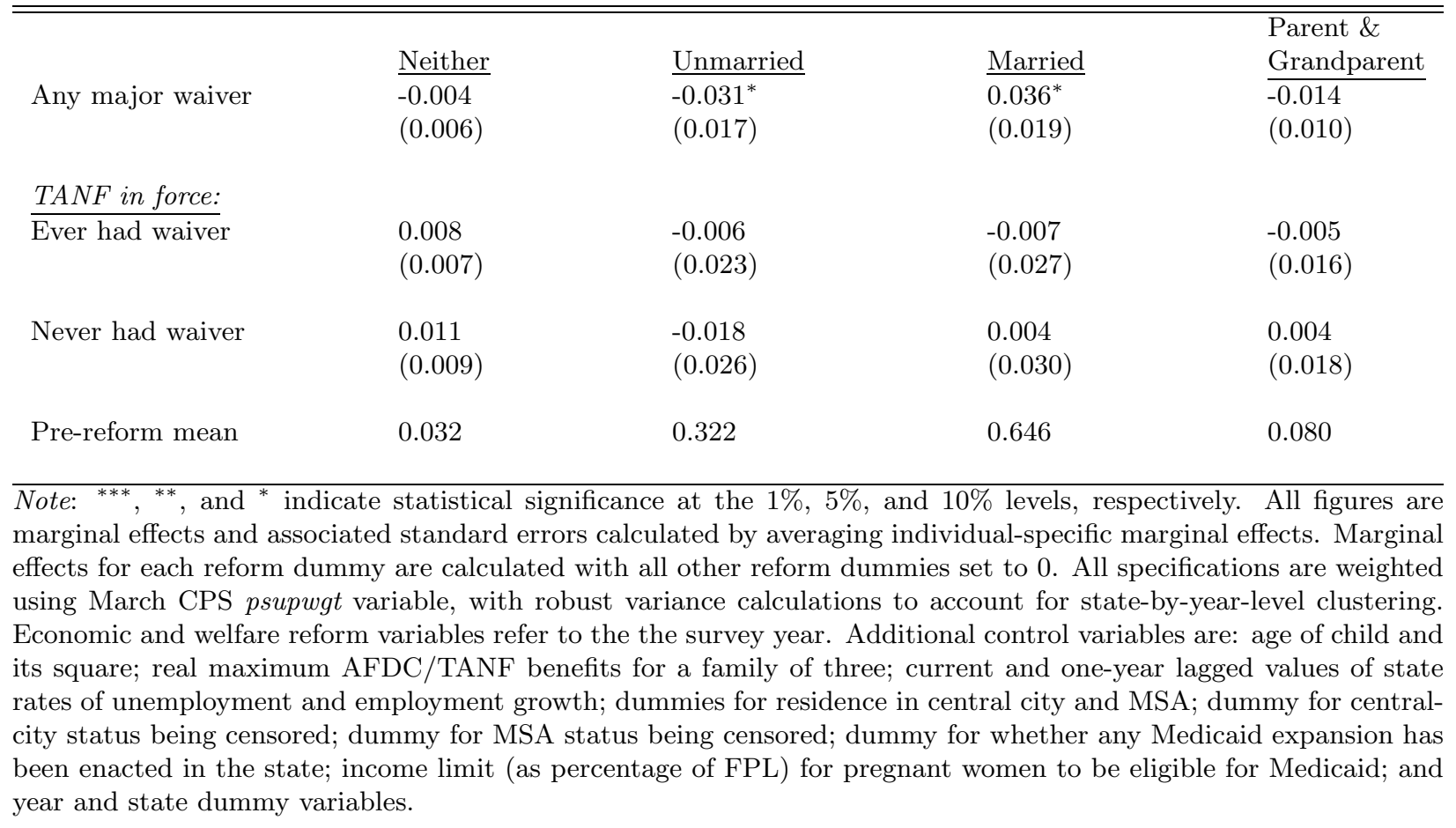


Table 8: Results for white sample, effects unconstrained

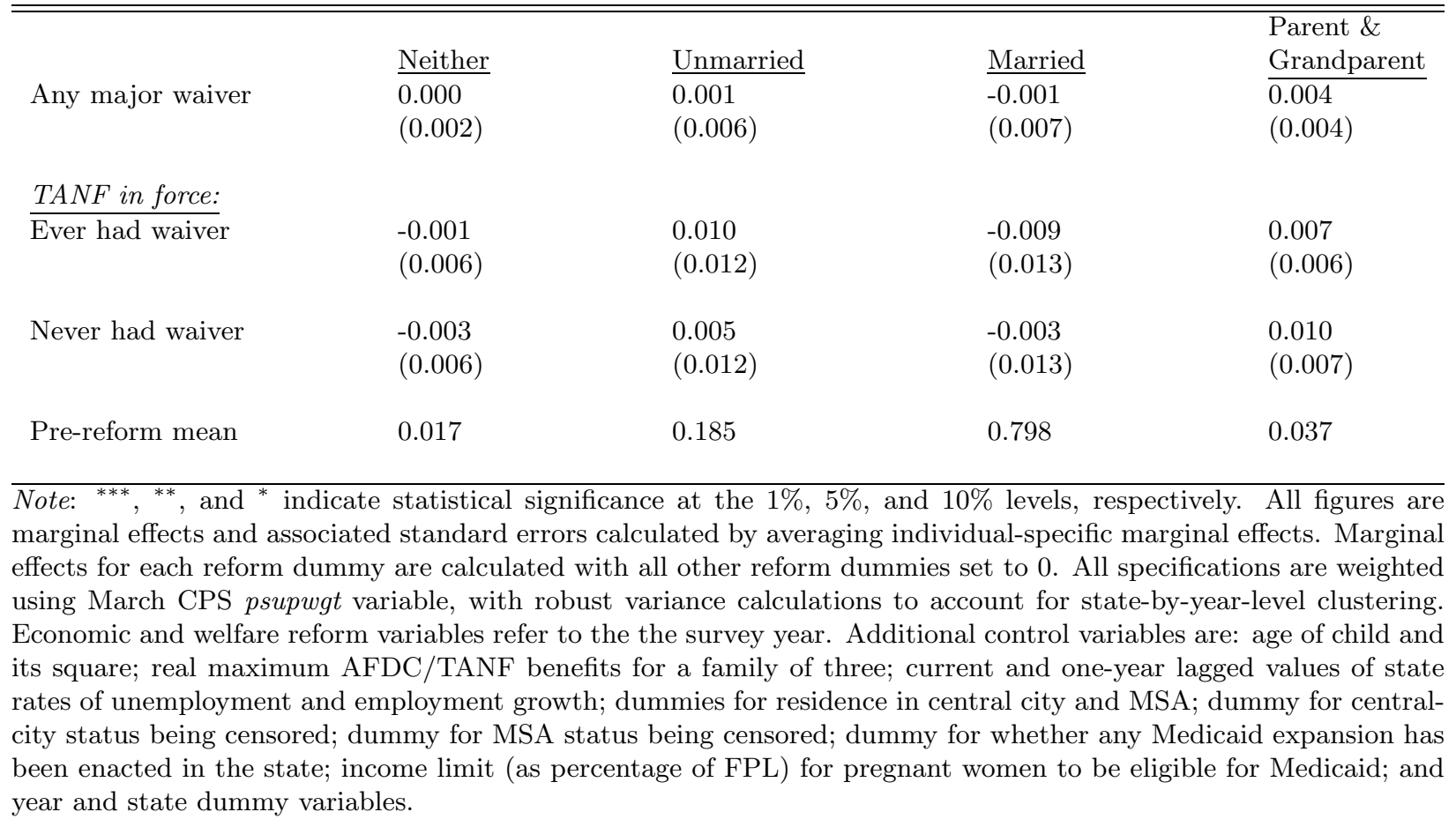

